\title{
Social practices, moral frameworks and religious values in the lives of older people
}

\author{
Carmel Gallagher
}

\section{Introduction}

This chapter aims to explore aspects of social norms and values in the everyday lives of older people in Ireland. It examines social practices and community participation among older people in one urban and one rural location, ${ }^{1}$ focusing on people's leisure interests, their involvement in clubs, their religious practices, voluntary work undertaken by them, their relationships with kin, friends and neighbours, help given and help received, their use of social services and their informal interactions. Thus it seeks to throw light on how older people live from day to day in neighbourhoods and communities: how they interact, what their social activities are, and to what extent these activities contribute to the meaningfulness and satisfaction in their lives. Many theoretical and empirical approaches in sociology depict older people's experiences in very individualistic terms. This study showed, in contrast, that communal interactions are highly significant to the older people concerned and that social values are crucial to how they live their lives. These values are often embedded in religious beliefs, but we shall emphasise here the ways in which these give rise to forms of friendship that are central to sustaining older people's lives.

The chapter begins by exploring the religious practices and helping activities of older people in their localities, both through formal groups and informally. It emphasises the moral frameworks, explicit and implicit, in their lives. We then examine the links between religious belief/practice and social connectedness, highlighting the significance of religion for personal meaning and the importance of social ties embodied in religious communities. While connectedness itself is not examined in depth here (see Gallagher, 2008), we shall refer to many aspects of community, social capital and friendship. The key arguments are that friendship and community are central to the creation of a more habitable social world and that older people contribute significantly to the lives of others through what they do and how they interact. To this extent older people live according to wise social practices and these practices enhance both personal and communal well-being. 
This study was based in two locations. Rathmore, the primary research site, is a suburban area of Dublin, and the secondary research site, Rathbeg, is a rural area in Donegal, in the North West of Ireland. A multi-method approach was used to seek insights into older people's lives in these locations. We carried out an interview-based survey of 165 older adults in Rathmore; and ethnographic observations were conducted extensively in many settings and centres in both localities. The range of social and communal settings involved included sport and social clubs, day centres, churches, voluntary groups, pubs, special interest groups and community events. Both quantitative and qualitative data were gathered in both locations so as to examine patterns and contexts of participation across a range of arenas. ${ }^{2}$ What did they show us about social practices around religion, volunteering and informal helping?

\section{Religious practices and beliefs in Rathmore and Rathbeg}

Religious practice was strong and significant in the lives of the older people in Rathmore and Rathbeg. Not surprisingly, though, different approaches and emphases were evident in relation to religion and spirituality (note that religion and spirituality were not expressly distinguished here). Despite the limitations of survey data in eliciting the personal meaning of religion, respondents nonetheless provided insights into their beliefs and the importance of their religion in coping with life and as a source of ultimate meaning. Furthermore, ethnographic observations revealed the practices and contexts of public religious activities. Moral frameworks were strongly shaped by membership of Christian churches. However, participation in other groups was also associated with positive values. Indeed, it appeared that a plurality of groups - voluntary, leisure and community development as well as religious - enhanced people's experience of connectedness. Thus, social worlds of meaning were created through interactions in an array of groups, of which religious groupings formed part.

\section{Churchgoing}

Reflecting the religious composition of the population in Ireland, ${ }^{3}$ the overwhelming majority of the sample in Rathmore were members of the Catholic Church, a handful were members of the Church of Ireland and a small percentage were not members of any church or were agnostic. Religious practice was clearly important to the vast majority. Levels of regular church attendance were very high; almost one third of respondents attended Mass daily while about $40 \%$ attended at least two or three times a week. A further $40 \%$ attended Mass or religious service weekly, making a cumulative total of almost $80 \%$ who attended Mass or religious service at least once every week. It is clear that this contrasts with overall trends of decline in religious practice in Ireland. According to surveys showing trends in weekly Mass attendance, there was a decline from $87 \%$ of Catholics to around 65\% of Catholics who attend weekly Mass from 1981 to 1998 (Fahey, 2002).This 
pattern has accelerated, with a 2002 IMS survey showing weekly Mass attendance at $48 \%$ by September 2002 (Irish Times, 20 September, 2002). In terms of variation by age and geographical location, the earlier surveys found that Mass attendance varied from $94 \%$ of older people in one diocese outside Dublin to $50 \%$ of all Dubliners to $41 \%$ among all 18-24 year olds in the country (Fahey, 2002).

As in Rathmore, the majority religion in Rathbeg is Catholicism. There are two other active churches - Church of Ireland and Presbyterian. ${ }^{4}$ There is a strong adherence to institutional religious practice among both the Catholic and Protestant communities. Many older people are daily Mass-goers. Respondents who could no longer attend Mass because of disability or infirmity said they missed going but, if they attended a day centre, Mass would often be included in the programme. In addition many parishes have parish radio, relaying Mass to people who are sick or housebound.

\section{How important was religious belief?}

In the Dublin survey, participants were asked whether religion or spirituality was important to them and any additional comments they made were also recorded. Almost $70 \%$ said they felt religion or spirituality was very important to them, $17.6 \%$ said that it was fairly important, while just less than $10 \%$ said it was not very important. It was clear that people had different approaches to religion and spirituality, some devotional and pious and others taking more questioning, reflective stances, and in some cases a critical and disenchanted attitude towards the Catholic Church. However, prayer seemed important to many, regular personal prayer, prayer in coping with difficulties and prayer through Mass-going and church attendance. Many older people say set prayers including the Rosary and prayers they learned as children, and they include in these prayers all their family and people they know who are ill or who have difficult personal predicaments. While high levels of Mass-going and prayer indicate strong belief among the older age group, it is also clear that these religious practices were developed from childhood. They were supported by rhythms of communal life and institutional forms of authority that do not prevail to the same extent in Irish society today.

At the same time current trends towards more private spirituality and secularism can be contrasted with the continuing popularity of forms of prayer such as Novenas. Novenas remain popular and have been incorporated into liturgies that attract high levels of 'voluntary' church attendance. For example, a Novena of Grace held in a church in Rathmore every March attracts a packed congregation on eight consecutive evenings. ${ }^{5}$ While public religious ritual is much less in evidence in contemporary Ireland than it was in the early decades of the state from the 1920s on, a significant religious ritual that appears to be gaining in popularity is the annual graveyard Mass taking place in many towns and villages in Ireland. Family members gather at the graves of their deceased relatives while an open-air Mass is celebrated. In Rathbeg this event is attended by most villagers whether or not they are regular churchgoers. Relatives travel from other localities 
including a diaspora living in other parts of Ireland and abroad who often plan their holidays to coincide with the graveyard Mass. Family members and other relatives make a special effort to be there, showing that such rituals are important in acknowledging the life of a deceased person and their place within the family and community.

\section{Religion and sociality}

The importance of social ties embodied in religious communities is evident in the lives of older people in Rathmore and Rathbeg. For many people who went to Mass daily or a few times a week, Mass was built into the structure of their day and had a social aspect to it. One man who attended Mass two or three times a week said: 'It gets you on an early start and you meet people.' Another respondent who attended daily Mass said:

I get up at 7.00 every morning. I know the people who live around [name of area]. After Mass every morning we have a chat. I meet fellas, hear the news, what's going on ... they're well up to date on everything. One man I speak to - I don't know his name - I chat about Gaelic football with a neighbour on the ' $\mathrm{X}$ ' Road and I don't know his name. (Interview, July 2002)

It might be argued that membership of a common moral community, in this case membership of the Catholic Church, makes intrusion in the form of greeting and chatting after Mass 'legitimate'. But there were many interactions such as these in other settings, which can be interpreted through a particular understanding of friendship. It will be argued here that such place-based friendships help to create enclaves that encourage tolerance and other-regarding behaviour.

Older people are particularly active in parish work. Indeed many of the respondents said that it was older people who do the bulk of work in parishes, and the researcher found much evidence of this. Church groups were the most common group in which respondents were involved, with $15.2 \%$ of the Rathmore sample helping in their church in some capacity. The types of work that the older adults did in their parishes included membership of parish councils, serving as Ministers of the Word (reading the scriptures at Mass) or Ministers of the Eucharist (giving out the Eucharist at Mass), cleaning the church, helping to prepare the Liturgy, helping with the church collection, singing in the church choir, helping with fund raising and so on.

In the study, involvement in a club or a formal social group was selected as one of five indicators of connectedness and many of the most connected respondents proved to be active in church groups. The social capital literature recognises the importance of both organisational and diffuse social ties for building up trust, generalised reciprocity and democratic practices. However, social capital theorists disagree on the exact nature of associational life that is said to be conducive to 
different forms of social capital. A very striking aspect of involvement in churchbased groups among the older people in this study was how differentiated it was by social class. There was a strong statistical correlation between involvement in church-based groups and belonging to a white-collar background. Within the social capital literature, Hall (1999) has drawn attention to a widening difference between the levels of social capital available to the working classes and the middle classes, arguing that 'the forms of civic involvement available to the least privileged are more fragile in the face of secular trends' (Hall, 1999: 458). Such class differences in community participation might therefore be fruitful areas of attention in future research.

\section{Religion, spirituality and well-being}

While much work has been conducted on religion and health in the US, it is only recently that the social-gerontological and policy literature in the UK has begun to recognise the centrality of spirituality and religion to well-being in older people and to debate and reflect on the implications of this for care of older people ${ }^{6}$ (see, for example, Jewell, 2004). In Scotland, for example, Harriet Mowat (2004) has explored the links between successful ageing and the idea of the spiritual journey. A longitudinal study in the UK, the Southampton Ageing Project, found evidence of decline in older people's allegiance to the Christian religion (Coleman et al, 2004). However, the fact that they ceased to be members of the Christian churches did not necessarily mean that they had lost their beliefs or that they lacked spiritual needs (Coleman et al, 2004: 186). Indeed, the authors argued that the churches should not take their older members' faith for granted and should not pass lightly over their obligations to their older members (Coleman et al, 2004: 185).

While spirituality has emerged as a separate subject of investigation from religion and is often contrasted positively with religion, especially in the UK literature, the two concepts are closely interrelated. Commentators such as Coleman have questioned the growing polarity between religion and spirituality, while Dillon and Wink's (2007) longitudinal study of older people in California has demonstrated that both church-centred religiousness and spiritual seeking enhance social and personal functioning for older adults. Coleman has suggested that, for older people in particular, talk of the spiritual is intimately associated with religion: 'Even getting them to speak about spiritual beliefs outside of the context of religious beliefs is not easy, although not impossible' (Coleman, 2006, quoted in Burke, 2007: 54).

In the Californian study the authors examined the consequences of being religious and being spiritual. Dillon and Wink's (2007) study suggests that religion, which was defined by belief in God, prayer and attendance at communal worship, is closely related to connectedness with other people and sense of community. The authors found that spirituality, which was defined by non-tradition-centred beliefs, sense of connectedness with a sacred other and involvement in practices 
such as meditation, was closely related to personal development and inner awareness. They also found that religion was positively associated with several dimensions of everyday functioning, with concern for others and a commitment to the social good, with life satisfaction, and with cushioning against some of the adversity and loss associated with old age (Dillon and Wink, 2007:215-16). Those who were religious showed higher levels of life satisfaction than did their nonreligious or spirituality-seeking peers. Furthermore, being religious provided a strong buffer against depression. However, both religious individuals and spiritual seekers preserved their sense of control in the face of adversity (Dillon and Wink, 2007: 204). Dillon and Wink found that both religious and spiritual individuals participated in a greater range of social activities and personal hobbies, and more frequently, than those who were neither religious nor spiritual. Furthermore, the positive association between religiousness or spiritual seeking and everyday purposeful activities was independent of good physical and mental health (Dillon and Wink, 2007: 214-15).

\section{The significance of religion in the lives of older people}

For many older people in Irish society, religion is interwoven into their lives and can be observed in their public religious practices, their private prayer, their use of language and their understanding of religion as a resource to cope with adversity. In an interview in Rathbeg an older resident spoke about deceased members of the community known to both him and the researcher. After each deceased person's name he invariably added: 'God be good to him and all those belonging to him' in a natural way that suggested that faith and religion were not compartmentalised in his life. Inglis (1998) has commented on the embeddedness of religion in everyday life in Irish society in the past. He conceptualises the declining position of the Catholic Church as a dilution of the moral influence of the Church, which symbolically dominated Irish life in a pervasive way (Inglis, 1998: 18). However, Cassidy (2002) has reviewed the impact of modernity on religious beliefs and practices in Ireland based on survey data related to the period 1980 to 2000 . He finds evidence of significant decline in three areas, namely, the belief in the moral authority of the Catholic Church, attendance at religious services and confidence in the Catholic Church in Ireland. However, he also finds little evidence of the growth of secularisation of Irish society leading to a loss of a sense of the spiritual, or to a decline in either the belief in traditional core Christian doctrines or the sense of the importance of God, religion or prayer in the lives of Irish people (Cassidy, 2002: 40-1).

Religious practice is no longer enforced in the same way in a pluralistic urbanised Ireland by the norms of small communities or by the rhythms of communal life. However, it retains both social and personal significance for the majority of older people and for significant numbers of the general population in Ireland. It seemed clear in this study that people who attend Mass regularly see it as giving consistent meaning to their lives. Moreover, the fact that older people 
who cannot attend Church in their locality will participate through televised or radio Mass, or seek opportunities to attend Mass at a day-care centre, clearly suggests that such religious practices are deeply meaningful to our respondents. However, it is clear from the UK experience and from trends in religious decline in Irish society that older people's adherence to religion and the cultural resource that religion represents should not be taken for granted. To explore this cultural resource in more detail, we shall now turn to the interconnections between religion and how older people engaged with others.

\section{Religious values and altruism}

As we have already indicated, churches have been seen in the social capital literature as strong repositories of positive communal values (see, for example, Gill, 1999; Davie, 2000; Herbert, 2003). Putnam (2000: 66-7) argues that, in the US, religiosity rivals education as a powerful correlate of most forms of civic engagement. Research in Britain by Gill (1999) finds a statistically significant correlation between participation in voluntary service groups and churchgoing. Furthermore, in Gill's work the forms of voluntary activity most closely related to membership of a religious group are services, residents'/tenants' associations, women's groups, political party, pensioners and trade union groups. In contrast, sports and social club membership are least closely related to religious group membership.

\section{Volunteering and churchgoing}

Approximately 30\% of older people in the study of Rathmore and Rathbeg did some form of voluntary work, mainly charitable, church or community development. This is somewhat higher than the rates suggested in other studies; for example, a report on volunteering in Ireland suggested a rate of $25 \%$ for this age group (National Committee on Volunteering in Ireland, 2002: 16-17). In the present study, while there was a statistically significant correlation between churchgoing and volunteering, it was not as strong or as clear-cut as in Gill's (1999). Older people who went to church two or three times a week were the group most likely to volunteer while those who went on a daily basis or once a week were equally likely to volunteer. Those who were irregular or non-churchgoers were less likely to volunteer.

It appears that the same values and dispositions are often involved in religious practice and volunteering. This may be more pronounced in Britain where churchgoing is a minority activity, ${ }^{7}$ and belonging to and practising one's religion is perhaps more intentional. In the present study older people who go to church a couple of times a week may be displaying a more purposive approach to how they choose to spend their time than either daily or weekly churchgoers. Perhaps it suggests an effect of being a person who, while very committed to church, is measured in their religiosity, neither formulistic nor pious in their religious 
practice. While the value base of Christianity strongly urges practical social concern for others, undertaking voluntary work is a conscious action that involves making room for it among one's other concerns.

\section{Helping and positive neighbouring}

Apart from formal voluntary work, the extent to which older people in the study helped others informally was very striking. Positive neighbouring was strongly evident in both Rathmore and Rathbeg. Older people both gave each other and received considerable amounts of practical help, and helping activities contributed to satisfaction with life both for givers and receivers. Forty per cent of the sample said they helped someone outside their own household while $14.5 \%$ said they received informal help with daily tasks from someone outside their household. Neighbours were the most frequent recipients of the respondents' help, followed by their own children or grandchildren. Help that the study participants gave to their neighbours ranged from providing companionship and giving lifts to personal care and house-maintenance tasks. ${ }^{8}$ Many people spoke about the practical help and support they received from neighbours in their day-to-day lives. A female interviewee who lived alone said:

They [neighbours] call into me ... I can't go out. One phones me every night. They're very good to me. (Interview, June 2002)

A recurring theme in the interviews in Rathmore and Rathbeg was how helpful, considerate, dependable and friendly people's neighbours were. One-to-one relationships with neighbours and friends involving support and practical help were vital for those experiencing incapacity and those living alone. However, it was clear that positive relationships with neighbours enhanced life both for those with and those without significant kin or friendship networks.

In addition to overt forms of helping, there were many examples of older people giving encouragement to each other in unobtrusive ways that demonstrated kindness and understanding. This was more than general valuing of good neighbours or feelings of general goodwill towards those in one's locality. In one neighbourhood, a group of women looked after their neighbour who was developing symptoms of dementia by supporting her in continuing normal social interaction. They did this by unobtrusively monitoring her movements in the neighbourhood and inviting her to accompany them on short trips to the shops and to social events. They encouraged her to continue to host a small prayer service in her home and then helped her to provide hospitality at it.

\section{Explicit and implicit Christian values}

The moral basis of neighbourliness can be understood as an expression of reciprocity (Bulmer, 1986:10) and/or as an expression of the Christian injunction 
to 'Love your neighbour'. The relationship between altruism, reciprocities and neighbouring has been explored in depth by Bulmer and Abrams in their work on neighbouring (Bulmer, 1986). In his empirical work on Good Neighbouring schemes, Abrams argues that altruism is closely associated with reciprocities and entails benefits to the giver as well as the receiver. In a slightly nuanced explanation that introduces the idea of generosity, Bulmer suggests that there is an 'inexpressible' reciprocity involved; while his Good Neighbours got as much as they gave they found it very difficult to give an account of what exactly it was that they received:

Belief in the altruistic nature of the action and attachment to a norm of beneficence as distinct from a norm of reciprocity appeared to be crucial conditions upon which the acts of giving and helping depended. (Bulmer, 1986: 108)

In the Christian tradition, the concepts of charity and love call for a dimension of 'gratuity' in the Christian person's relations with others (Martin, 2006). The Christian ideal of gratuitous love is close to the 'norm of beneficence' that Bulmer identifies.

Reciprocities are not a simple question of 'give and take' involving calculated exchanges. Both Abrams and Bulmer demonstrate how both specific and generalised reciprocities can be understood in terms of a series of reciprocal relationships where the person receiving care actively responds and stores up basic experiences and ethical obligations, which may emerge later on in altruistic behaviour on their part or be given expression in other sets of reciprocal relationships. Bulmer makes the further suggestion that generalised reciprocity among neighbours might develop into commitment and friendship. In Rathmore and Rathbeg, there were many examples of informal helping that involved a considerable commitment to non-immediate relatives, neighbours and friends. The helping activities of the respondents went well beyond the everyday sociability and civilities of communal life. It was evident that helpers had a strong sense of affinity with others and a strong sense of obligation consistent with the Christian injunction to 'Love your neighbour'. It was also evident that helpers got satisfaction from their work and from the friendships that were created.

A resident of Rathbeg, who was a committed practising Catholic and retired nurse, described her motives for nursing a sick cousin over several years in strong altruistic terms:

I looked after [person's name] when she was ill, a cousin of mine. I looked after her for years - she had several small strokes ... I took it as my duty I suppose, maybe because she didn't have anyone else. I was full-time able to do it and I did it ... No, I didn't even think about it ... I mean I just did it and that was all - no second thoughts about it. (Interview, March 2001) 
Many volunteers displayed social concern in Christian terms, although this was not the only factor associated with volunteering. For some interviewees their Christianity was explicit in the terms in which they spoke about their work. One man in Rathmore, who made a significant contribution in his locality by organising social events and by improving the environment through cultivating plants and flowers, appeared motivated by a strong sense of Christian duty. He spoke about how he had coped with considerable personal difficulties and the degree to which he was motivated by a strong sense of God in his life. The religious minister in the parish described the man's work in religious/vocational terms as follows: 'God bless [name of man's] Ministry at [name of area]'. Other residents cited the man's work as an example of positive involvement in the community and made comments such as:

There's one man in the complex and there's not enough hours in the day for all he does.

For others, it did not become clear to what extent they were motivated by their religious beliefs, but their Christian or humanistic ethos was implicit in how attuned they were to the lives of other people in their locality and in their willingness to undertake practical work to help them. One of the main organisers of a public/voluntary initiative to develop sheltered housing and day-care facilities for older people in the environs of Rathbeg spoke about his reasons for taking on the task:

I saw lovely older people who felt in the way in their own homes ... Rejection is the worst thing that can happen to anyone ... I wanted to make sure people felt wanted again and never feel a nuisance.They feel they are important now - instead of a nursing home they got a new life and made new friends. (Interview, August 2003)

It is not possible to say to what extent this man was religious or what his personal belief-system involved. ${ }^{9}$ However, his practical concern for his 'neighbour' was strongly evident in the terms in which he spoke about his work, and his interactions and friendship with the day-centre users were clearly a source of great personal satisfaction to him. His concern and commitment were of major social benefit in a scattered rural community, particularly for the older people who attended the day centre or lived in the sheltered accommodation. Previously such individuals would have remained somewhat isolated in their homes, without peer companionship, or would have had to go to residential care in a place some distance from their own locality. In the study we observed many examples of impressive day-care and residential facilities that resulted at least in part from the vision, commitment and energy of volunteers in Rathbeg. ${ }^{10}$ 


\section{Friendship in Rathmore and Rathbeg}

The concept of friendship emerged as a central idea in interpreting the nature of connectedness among older people in Rathmore and Rathbeg. All the different types of friendship documented, including long-standing one-to-one friendships, friendships among club members and more generalised friendship among neighbours, appeared to involve the development of shared moral understandings. As well as fun and sociability, which were key processes observed in many groups, participants in senior citizens' clubs, active retirement associations, church groups and community groups displayed kindness and a sense of obligation towards others. For example, the Secretary of an active retirement association (ARA) in Rathmore spoke about how she encouraged quieter people to participate at whatever level they were comfortable with. She praised members who, she said, were always supportive and protective of each other and added that they gave particular attention to anyone who was demonstrating signs of early dementia.

A form of generalised friendship was evident in many daily interactions in Rathmore and Rathbeg. Edmondson (2001) has previously described a form of 'distributed intimacy' in her ethnographic work in the West of Ireland. She suggests that communicative forms associated with traditional societies mean that emotional satisfaction may be derived from daily contacts spread throughout the locality in which one lives and does not necessarily rest only on intimate and personal relationships (Edmondson, 2001: 68). The Rathmore and Rathbeg study did emphasise the significance of cultural practices involving greeting and conversing with others in one's locality whom one does not know intimately, though we would interpret it somewhat differently.

These findings also suggest a contrasting understanding of friendship to that advanced by some writers, including Pahl (2000), for example, who views friendship as 'a relationship built upon the whole person that aims at a psychological intimacy' and that has 'connotations of freedom, choice, individuality and, crucially, subversion.' (Pahl, 2000: 163, 166). The elements of friendship identified in this study appear closer to the traditional idea of friendship as developed by Aristotle and Cicero and understood in the Christian concept of 'personhood', involving an essential moral component (Bellah et al, 1996: 115). On the basis of the present study, it is suggested that friendship among older people is best seen as a relational and multidimensional concept involving a number of processes such as fun, sociability, solidarity, obligation, respect and acknowledgement.

\section{Moral values and connectedness}

The study found that interactions within localities through helping activities, religious/voluntary groups, leisure activities and informal interactions help to create social and moral worlds where people experience a sense of involvement, belonging and fulfilment. Through dense reciprocal relationships involving kin, neighbours and friends, as well as through the work of intermediate groups such 
as voluntary groups, clubs and church-based groups, enclaves of sociality are cocreated where older people experience a sense of worth and purpose. It can be argued that, for life to be satisfying, people must be connected within enclaves of sociality that provide opportunities for sociability and friendship, for learning and personal development and for giving as well as receiving (Gallagher, 2008: 319).

Activities such as volunteering and informal helping involve communicating an agreed set of expectations about appropriate standards of behaviour and thus help to create a more habitable social world. Some older people stand out as 'creators of community' in both their everyday interactions and their broader social concern for others in the wider community. The idea of 'good example' was suggested by the lives of many individuals who were exemplars of positive neighbouring, and many people explicitly and spontaneously acknowledged the work of such individuals in their localities. Putnam, in his work on declining social capital in the US, has emphasised the interactive effects between friendship, reciprocities and good example in his discussion of the ripple effects of 'doing good' (Putnam, 2000: 121-2). Furthermore, he suggests that, while doing good for other people may be laudable, it is not part of the definition of social capital. It is, he suggests, when we do things with others that we reinforce bonds within the community (Putnam, 2000: 116-17).

Charles Taylor (1994) has argued that a sense of what is good needs to be articulated and given expression so that people can have possibilities for making moral choices (Taylor, 1994). A vision of what was good is certainly articulated in many of the groups in Rathmore and Rathbeg, in particular social clubs, voluntary/community groups and church groups. Positive moral orientations were also expressed through common cultural practices such as greeting others, social practices at funerals, helping at times of difficulty and so on. Such practices can be regarded as representing collective wisdom - a cultural resource that entails both personal and communal benefits. From a public policy point of view it can be argued that a good life in old age must be understood in terms of community - that older people, regardless of any limitations of physical or mental capacity, must have the opportunity to remain involved with others and engaged in meaningful activity (Gallagher, 2006: 70).

\section{Summary: a culture of friendship}

In the course of compiling rich details of the lives of older people in two geographic localities in Ireland, we have found evidence of strong moral and religious values in the lives of older people. These are embedded in social practices that arguably are the foundations of connectedness. Contrary to suggestions that Ireland is now a secular, post-Christian society, we have highlighted the influence of religion as a source of ultimate meaning, as well as the importance of social ties generated through common membership of Christian churches. Christian values, either explicit or implicit, were evident in the lives of those who helped others. 
What constituted a good life for older people in the study were social interactions and helping activities involving family, neighbours and friends. Being connected with others in one's locality or community through informal helping, voluntary activities or communal leisure was associated with satisfaction with life and sense of purpose. Informal and formal helping were key aspects of connectedness that contributed to satisfaction and enjoyment of life for givers and recipients alike.

Older people in the study were strongly other-regarding. The contribution made by individual older people was very significant; they sometimes even provided key inputs to public policy initiatives. While some stood out in terms of their voluntary and community work, it was not essential to be a social activist to influence the lives of others positively. Small meaningful interactions enhanced the lives of older people involved in such reciprocities. The moral and sociable aspects of friendship were highlighted in the types of friendship observed in Rathmore and Rathbeg. People valued the kindness and helpfulness of neighbours that was demonstrated through many helping tasks, visiting and support at times of particular difficulties. In many cases neighbours were friends. Friendships in socio-spatial settings involved obligations that appeared to arise out of sharing life space, habitual interactions and knowing and understanding one another's situation.

Cultural practices such as greeting and chatting and meeting for communal religious or social celebrations represent a form of collective wisdom: they engender behaviour that is important to living good lives, both for the actors concerned and for those affected by what they do. Here locally based groups provide important contexts for positive sociality. Friendship creates enclaves of sociality where individuals experience a sense of belonging and purpose. We might therefore argue that friendship and community are key to the achievement of a good life and that older people through their wise interactions and social practices are a vital resource in our society.

\section{Notes}

1 'The participation of older people in their communities', PhD study, National University of Ireland, Galway, 2005, based on explorations carried out between 2000 and 2005.

2 The data was integrated to develop typologies of the main ways in which older adults in Rathmore and Rathbeg are connected within their communities and an index of connectedness was developed. The chapter will not present data on these overall measures, but detailed findings are available in Gallagher (2008). Note that, here, the quantitative data is derived from the Rathmore survey while the qualitative data is derived from both study areas.

3 The 2002 Census classified the population of Ireland by religious denomination as follows. Catholic: $88.4 \%$, Protestant denominations (Church of Ireland being the 
largest): $3.8 \%$, Christian (unspecified): $0.6 \%$, other religions: $1.6 \%$, no religion/not stated: $5.6 \%$ (2002 Census of Population, CSO).

${ }^{4}$ While membership of these Protestant churches is proportionately small, both churches have regular church services and members are active in church-related work. The Protestant church is strong in Donegal compared with its overall numerical strength in the Republic of Ireland, making up $10.8 \%$ of the population of the county (Derry and Raphoe Action, 2001:2).

5 A Novena is a sequence of nine days' prayer, usually involving Mass each day, with a themed reflection and set of readings running through the period. Novenas of Grace are associated with the life of St Francis Xavier. In rural Ireland, Novenas are fairly large-scale social events.

${ }^{6}$ Within the Christian churches in the UK, initiatives have been undertaken by the Christian Council on Ageing and the Methodist Homes for the Aged Care Group (Jewell, 2004:13-14).The non-denominational organisation, Age Concern, England has also developed initiatives to respond to the spiritual needs of older people in a secular society (Burke, 2007).

7 In the 1950s about 50\% of the population of England attended some form of religious service every week in contrast with about $10 \%$ today, and this includes all faith communities (Burke, 2007: 4).

${ }^{8}$ Visiting was the most frequently mentioned helping activity - for example, visiting a neighbour who had reduced mobility or visiting a neighbour in hospital. Tasks done for neighbours ranged from instrumental help to more general 'watch and ward' activities. Instrumental help given to neighbours included doing household chores, running errands such as collecting medical prescriptions, carrying household refuse bins in and out, giving lifts, looking after a pet, shopping, providing a meal, and doing maintenance jobs such as gardening or repair work. Many spoke about helping if a neighbour was ill.

9 This informant was not a survey participant and was not questioned about his religious beliefs or practices.

10 Social care services for older people in Ireland are delivered through a mixed economy of welfare model. Many day-care services are provided through a partnership between public bodies and voluntary bodies. A fuller description of such centres can be found in Gallagher (2008). 


\section{References}

Bellah, R., Madsen, R., Sullivan, W., Swidler, A. and Tipton, S. (1996) Habits of the heart: Individualism and commitment in American life, Berkeley, CA: University of California Press.

Bulmer, M. (1986) Neighbours: The work of Philip Abrams, Cambridge: Cambridge University Press.

Burke, G. (2007) Spirituality: Roots and routes, London: Age Concern.

Cassidy, E. (2002) 'Modernity and religion in Ireland: 1980-2000', in E. Cassidy (ed) Measuring Ireland: Discerning values and beliefs, Dublin:Veritas, pp17-45.

Coleman, P.G. (2006) 'Spirituality, health and ageing', David Hobman Memorial Lecture, Age Concern England and King's College London, 30 January.

Coleman, P.G., Ivani-Chalian, C. and Robinson, M. (2004) 'Religious attitudes among British older people: stability and change in a 20-year longitudinal study', Ageing and Society, vol 24, no 2, pp 167-88.

Davie, G. (2000) Religion in modern Europe, Oxford: OUP.

Derry and Raphoe Action (2001) Protestants in community life - findings from a Co. Donegal survey, Raphoe: Derry and Raphoe Action.

Dillon, M. and Wink, P. (2007) In the course of a lifetime:Tracing religious belief, practice and change, Berkeley, CA: University of California Press.

Edmondson, R. (2001) 'Studying civic culture ethnographically and what it tells us about social capital', in P. Dekker and E.M. Uslaner (eds) Social capital and participation in everyday life, London and New York: Routledge, pp 59-72.

Fahey,T. (2002) 'Is atheism increasing? Ireland and Europe compared', in E. Cassidy (ed) Measuring Ireland: Discerning values and beliefs, Dublin:Veritas, pp 46-66.

Gallagher, C. (2006) 'Social policy and a good life in old age', in E. O'Dell (ed) Older people in modern Ireland: Essays on law and policy, Dublin: First Law, pp 48-71.

Gallagher, C. (2008) The community life of older people in Ireland, Oxford: Peter Lang.

Gill, R. (1999) Churchgoing and christian ethics, Cambridge: Cambridge University Press.

Hall, P. (1999) 'Social capital in Britain', British Journal of Political Science, vol 29, no 3, pp 417-61.

Herbert, D. (2003) Religion and civil society - rethinking public religion in the contemporary world, London: Ashgate.

Inglis, T. (1998) Moral monopoly - the rise and fall of the Catholic Church in modern Ireland, Dublin: Gill and Macmillan.

Jewell, A. (2004) 'Nourishing the inner being - a spirituality model, in A. Jewel (ed) Ageing, spirituality and well-being, London: Jessica Kingsley, pp 11-26.

Martin, Rev D. (2006) 'In a changing Ireland has social care practice left religious and spiritual values behind?', address to seminar, 3 April, Centre for Social and Educational Research, Dublin Institute of Technology.

Mowat, H. (2004) 'Successful ageing and the spiritual journey', in A. Jewel (ed) Ageing, spirituality and well-being, London: Jessica Kingsley, pp 42-57. 


\section{Valuing older people}

National Committee on Volunteering in Ireland (2002) Tipping the balance - report and recommendations to Government on supporting and developing volunteering in Ireland, Dublin: National Committee on Volunteering in Ireland.

Pahl, R. (2000) On friendship, Cambridge: Polity.

Putnam, R. (2000) Bowling alone: The collapse and revival of American community, New York: Simon and Schuster.

Taylor, C. (1994) Sources of the self - the making of the modern identity, New York: University of Cambridge. 